Egypt. Poult. Sci. Vol. (41) (III): (507-523)(2021)

Egyptian Poultry Science Journal

http://www.epsj.journals.ekb.eg/

ISSN: 1110-5623 (Print) - 2090-0570 (Online)

\title{
GENETIC RESPONSE OF SOME BODY MALES MEASUREMENTS AND REPRODUCTION FOR GIMMIZAH CHICKENS SELECTED FOR BODY CIRCUMFERENCE
}

\author{
N.G. Boutrous
}

Anim. Prod. Res. Inst., Agric. Res. Cent, Egypt

Corresponding Author: Nabile G. Boutrous, Email: Nabiiiiiiile.s.b@gmail.com

Received: 29/06/2021

Accepted: $29 / 08 / 2021$

\begin{abstract}
Gimmizah (GM) chickens aiming to investigate the effect of selection for breast circumference at twelve weeks of age through six generations on some physical characters of males and hatchability besides estimating some genetical sire parameters among the selected generations. Two hundred and twenty hens besides twenty two males were randomly chosen from (GM) flock and considered as base population $\left(\mathrm{G}_{0}\right)$ composing pen's families (10hens and one male / pen). Day-old chicks produced from $\mathrm{G}_{0}$ were wing-banded and selected for breast circumference (BC) at 12-wk of age within families. Chickens were selected as parents of the next generation and continued throughout five generations. A total number of 6750 hatching eggs representing the six experimental consecutive generations were used for hatching trials. Data were collected for some physical parameters of GM males at 1 day, 8, 12, 25 and 45 weeks of age for six generations. Hatched male body weights $\left(B W_{1}\right)$ were significantly higher for selected line among $G_{0}, G_{4}$ and $G_{5}$ generations compared to those for control one. Selection for chicken BC significantly improved fertility percentage with advanced generations. Moreover, fertility percentage was significantly increased for selected chickens compared to those for control line at fifth generation.
\end{abstract}

Heritability estimates seem to be high for all body weights at studied ages through the sixgeneration ranked between 0.50 among the most ages and generations with 0.97 for $\mathrm{BW}_{8}$ and $\mathrm{BW}_{12}$ at $\mathrm{G}_{4}$.Also, $\mathrm{BC}$ represented high estimates of $h^{2}$ among the ages and generations ranged between 0.32 for $\mathrm{BC}_{12}$ at $\mathrm{G}_{5}$ and 0.69 for $\mathrm{BC}_{12}$ at $\mathrm{G}_{0}$. Genetic correlations between fertility and body weights among the studied generations were low differed between 0.10 up to 0.34 , with value of 0.28 for $\mathrm{BW}_{1}$ at $\mathrm{G}_{5}$. It is concluded from this study that fertility trait should be taken into consideration during selection of breast circumference, besides other breast measurements such as breast length and width should be included in the coming genetic selection program.

Key words:Chickens- Selection - Heritability- Fertility - Breast 


\section{INTRODUCTION}

The male growth profile is the single most important factor that correlates with flock fertility (Salahi et al., 2014). Fertility is a major interest trait in the chicken performance due to its effect on the chick output(Wolc et al., 2014). Genetic selection for traits such as growth rate and yield have been negatively associated with the expression of morphometric traits related to reproduction (Siegel and Dunnington, 1985). Selection for growth alone over several generations is likely to result a decline in fertility or in the ability of the mating for males (Brillard, 2004). Fertility problems were partially attributed to selection for increase body weight (Ogasawara et al., 1963) and modified breast measurements which affect the physical ability of the males to copulate (Carte and Leighton, 1969). Physical modification due to selection may impede semen transfer and impact on fertility (Zeller, 1971).

Norma skeletal development of chicken is important in terms of obtaining high level of fertility. Males with a good balance of shank length, keel length and breast width had a high fertility rate (Dudgeon, 2010). Also, Keel length is the most commonly estimates of frame size in breeder management and there are small differences among strains at the time of hatching (Gao et al., 2010).

The knowledge of genetic parameters like mean, variance and heritability along with genetic correlations of important traits is important and necessary for designing a breeding program for genetic improvement (Swayamprabha et al., 2018). The objective of the current study was to investigate the effect of selection for breast circumference parameters of Gimmizah chickens at twelve weeks of age through five generations on some physical characters for males such as body weight, breast length, breast width and hatching output. Also, this experiment was planned to estimate some genetic parameters such as heritability, additive genetic and genetic correlations for sires among selected generations.

\section{MATERIALS AND METHODS}

The present experiment was conducted on Gimmizah (GM) chicken males at ELSabahia Poultry Research Station, Agriculture Research Center. Two hundred and twenty GM hens besides twenty two males grown on litter were randomly chosen from the flock and considered as base population $\left(\mathrm{G}_{0}\right)$ composing pen's families (10 hen and one male / pen). Day-old chicks produced from $\mathrm{G}_{0}$ were wing-banded and selected for breast circumference (BC) at 12-wk of age within families. Birds were selected as the parents of the next generation and continued throughout other five generations. Average selection proportion of about $40-45 \%$ for hens and $5 \%$ for cocks were applied in each generation, one hundred and twenty hens and 12 cocks were selected to produce the next generation.families were consisted by randomly mating of one male from each sire family to a non-related ten females from each family to produce the next generations and continued throughout other five generations.

A total number of 6750 hatching GM eggs produced from chickens aged between 45-50 wks and representing the six experimental consecutive generations were used for hatching trials. Eggs were individually numbered and marked by sires for each generation then they were weighed prior the beginning of incubation in Egyptian-made incubator at $99.5 \mathrm{~F}^{\circ}$ and $55 \%$ relative humidity ( $\mathrm{RH})$ during 
Chickens- Selection - Heritability- Fertility - Breast

setting phase and $98.60 \mathrm{~F}^{\circ}$ with $65 \% \mathrm{RH}$ during hatching phase. Eggs were randomly distributed in trays as replicate in the incubator.

Eggs that failed to hatch and having full opportunity to hatch were broken out then examined macroscopically to detect the fertile eggs. Macroscopic fertility and hatchability of fertile egg percentages were detected for each sire families. Chicks that had fully emerged from eggs were wing banded and weighed to the nearest $0.1 \mathrm{gm}$. All these processes were continued through the studied six generations.

Data were collected for somephysical parameters of GM males at 1 day, 8, 12, 25 and 45 weeks of age for the studied six generations. The body measurements for all males in each family were taken as body weight (BW, gm), breast circumference $(\mathrm{BC}, \mathrm{cm})$ of the breast around the deepest region of the breast by tailor's tape role, breast width $(\mathrm{BD}, \mathrm{cm})$ from the point of depression to the sharp edge and breast length (BL, cm) from the chest bone to the end towards the abdomen region. All these measures were done for all GM males through the six generations according to Teguia et al. (2008).

\section{Statistical Methods}

In this process, individuals that are sire and do not contribute to the information for variance component estimation, i.e. individuals without records and a pedigree link to at least one other individual are replaced with an "unknown" code and eliminated from the list of the pedigree records (Meyer, 2006). The first step, the mixed model was defined to analyze the data, get the Restricted Maximum Likelihood (REML) estimates of the variance and covariance components. These estimates were used in the prediction equations of the additive values of all birds as directed by Sorensen and Kennedy (1984). The following animal model shown in matrix notation was used to estimate genetic parametersfor the fertility, hatchability of total eggs,BW, BC, BDandBL traits,as well as means of all traits. REML co variance components were estimated by series of multivariate animal models (allowing to estimate correlations among traits) using WOMBAT software (Meyer, 2006).

The model can be represented in matrix terms by

$\mathrm{Y}=\mathrm{Xb}+\mathrm{Za}+\mathrm{e}$

Where, $\mathrm{Y}$ is the vector of observations; $\mathrm{X}$ is the incidence matrix of fixed effects; $b$ is the vector of fixed effects (generation); $\mathrm{Z}$ is the incidence matrix of random effects; $a$ is the vector of random effects; $\mathrm{e}$ is the vector of residuals. Single-trait analyses were used to obtain estimates additive and heritability's, and these estimates were then used in a multipletrait analysis of all different traits to obtain genetic correlations among traits Genetic correlations were estimated using biraviate analyses with the same fixed effects in univariate models (Yavarifard et al. 2015).

Heritability was computed according to Boldman et al. (1995) as:

$\mathrm{h}^{2}=\frac{\sigma_{\mathrm{a}}^{2}}{\sigma_{\mathrm{a}}^{2}+\sigma_{\mathrm{e}}^{2}}$

Where $\sigma_{\mathrm{a}}^{2}$ and $\sigma_{\mathrm{e}}^{2}$ are variances due to effects of direct additive genetic and random error, respectively.

Numbers of preliminary analyses were done using SAS (2010) for checking listing all data. The following model was used:

$\mathrm{Y}_{\mathrm{ij}}=\mu+\mathrm{s}_{\mathrm{i}}+\mathrm{e}_{\mathrm{ij}}$

Where 
$\mathrm{Y}_{\mathrm{ij}} \quad=$ the phenotypic measurements for the individual from $\mathrm{j}^{\text {th }}$ sire.

$\mu \quad=$ general mean for the measurement.

$\mathrm{s}_{\mathrm{i}} \quad=$ effect common to all individual from $\mathrm{i}^{\text {th }}$ sire.

$\mathrm{e}_{\mathrm{ij}}=$ the experimental error.

Differences between each means were done according to Duncan (1955).

\section{RESULTS AND DISCUSSION}

Data of Table 1 represented some bodymales measurements and hatchability for Gimmizah chickens selected for breast circumference(BC) among six successive generations. Hatched male body weights $\left(\mathrm{BW}_{1}\right)$ were significantly higher for selected line among $\mathrm{G}_{0}, \mathrm{G}_{4}$ and $\mathrm{G}_{5}$ generations compared to those for control line.

Fourth and fifth generations showed increase $(p<0.05)$ of body weight at eightweek of age $\left(\mathrm{BW}_{8}\right)$ compared to those for other studied generations in selected line, while control line represented opposite trend with significant decrease of $\mathrm{BW}_{8}$. Moreover, $\mathrm{BW}_{8}$ was significantly increased for selected line compared to control at $\mathrm{G}_{0}, \mathrm{G}_{3}, \mathrm{G}_{4}$ and $\mathrm{G}_{5}$. Moreover, $\mathrm{G}_{4}$ and $\mathrm{G}_{5}$ the selected male line significantly surpassed the males of control one with respect to $\mathrm{BW}$ at 12,25 and 45 wks of age.

Apparently from data of this table that BC was significantly increased for selected and control birds of the fifth generation compared to those for the other studied generations for all ages. Breast circumferenceswere significantly increased for selected line compared to those for control regarding for $\mathrm{BC}_{12}, \mathrm{BC}_{25}$ and $\mathrm{BC}_{45}$.

Significantly, marked increase of breast width (BD) was detected in the selected males of $G_{4}$ and $G_{5}$ among the studied ages of 12, 25 and 45 weeks. Also, breast width was significantly $(\mathrm{p}<0.01)$ increased for selected line compared to those for control referring to $\mathrm{BC}_{12}, \mathrm{BC}_{25}$ and $\mathrm{BC}_{45}$ except those for $\mathrm{G}_{0}$ at $12 \mathrm{wks}$ and $\mathrm{G}_{1}$ at 25 wks of age.

The fifth generation of selection demonstrated significant increase of BL compared to those for other studied experimental generations. Generally, BL significantly increased for selected line compared to those for control regarding $\mathrm{BC}_{12}, \mathrm{BC}_{25}$ and $\mathrm{BC}_{45}$ at fifth generation.

Selection for $B C$ significantly $(p<0.05)$ improved fertility percentages with advancing generations. Moreover, fertility trait was significantly increased for selected line at $\mathrm{G}_{5}$ compared to all studied generations. Also, the significant improvement of fertility for selected line compared to control was observed in the $2^{\text {nd }}, 3^{\text {rd }}, 4^{\text {th }}$ and $5^{\text {th }}$ generations.

Hatchability of fertile eggs percentage represented significant improvement with advanced selection through generations as observed in fertility and the best value of hatchability was observed in the fifth generation. While the significant increase of hatchability for fertile eggs in the selected line was not noticed except for the fifth generation and the comparison between selected line and control was not observed among the $\mathrm{G}_{0}, \mathrm{G}_{1}$ and $\mathrm{G}_{4}$.

Results of the apparent significant increase of $\mathrm{BW}_{1}$ for selected line compared to control in $\mathrm{G}_{4}$ and $\mathrm{G}_{5}$ were supported by Dunnington and Sigel (1985) who found that the greater effect of selection had been observed for breast angle in later studied generations. Moreover, Abou EL-Ghar and Ragaa (2016) found the same results of body weight increase at 12 -wk of age for selected line compared to control,whereas, Merritt (1958) found that selection for breast width after four 


\section{Chickens- Selection - Heritability- Fertility - Breast}

generation had no significant influence on body weight.

Referring to the increase of $\mathrm{BC}$ for the selected line compared to the control among studied generations, Ragaa and Ashour (2014) came to the same outcome. Furthermore, Schmidt et al. (2006) found that there is response selection for breastdue toBC selection. Also, Ragaa and Ashour (2014) found that body measurements such as keel length and keel circumference had been increased by selection from one generation to the next one through three generations.

Genetic sire additive estimates of BW, $\mathrm{BC}, \mathrm{BW}$, and $\mathrm{BL}$ besides fertility and hatchability for Gimmizah chickens among six generations of selection for breast circumference are shown in Table 2. The results showed that genetic sire additive for $\mathrm{BW}_{1}$ ranged between 0.84 for $\left(\mathrm{G}_{2}\right)$ to 14.8 for $\left(\mathrm{G}_{4}\right)$ and ranged between 1.08 for $G_{2}$ to 46.38 for $G_{3}$ with respect to $\mathrm{BW}_{8}$. It appears from data of this table that very small variations were observed between the studied generations for body weight at 45 weeks while the high variations between generations were observed for $\mathrm{BW}_{8}, \mathrm{BW}_{12}$ and $\mathrm{BW}_{25}$. Also, referring to $\mathrm{BC}$, lowest estimate of additive genetic was detected for $\mathrm{G}_{1}$ at 12 week of age and the highest one for $\mathrm{G}_{3}$ at 25 weekof age. While, both of $\mathrm{BD}_{25}$ and $\mathrm{BD}_{45}$ represented lowest genetic additive for BD among the experimental ages and nearly closer among the studied generations. Regarding BL, highest estimates were observed for $\mathrm{G}_{4}$ compared to the other generations being $4.56,17.88$ and 2.67 for $\mathrm{BL}_{12}, 25$ and 45 , respectively. The genetic sire additive estimate of fertility percentage had increased from 0.84 at $\mathrm{G}_{1}$ to 1.85 and 1.83 for $\mathrm{G}_{4}$ and $\mathrm{G}_{5}$, respectively. The genetic additive for hatchability of fertile eggs represented almost thesome estimates among the generations except that for $\mathrm{G}_{3}$. As previously indicated, there is little collaborative data on the genetic additive of the studied body measurements of Gimmizah males due to selection for BC of birds at 12-wk of age.

The results of genetic additive for $\mathrm{BW}_{1}$ are in line with those previously mentioned by Tongsiri et al. (2019)who reported that genetic additive estimates ranged between 0.84 to 14.8 . The same authors added that additive genetic effect of the sires becomes critical and significantly affected the body weight in the subsequent ages. Also, Gwaza et al. (2018) reported that selection for body weight significantly affected weight at weeks four and above. The variation in genetic additive of the breast measurements (BC, BD and $\mathrm{BL}$ ) for the studied ages of Gimmizah males among the six generations of selection are in harmony with those reported by Barbato et al. (1983) who mentioned that those variations were moderate heterotic. Regarding the direct additive for fertility and hatchability, Ayman et al. (2013) reported that direct additive for fertility and hatchability of fertile eggs were -0.22 and 3.72, respectively for crossing between Mandarah and EL-Salam chicken strains.

Heritability estimates $\left(h^{2}\right)$ for male BW, BC, BD, BL, besides fertility and hatchability of fertile eggs are given in Table 3 Heritability estimates seem to be high for all body weights at studied ages through the six generations ranked between 0.50 among the most ages and generations with 0.97 for $\mathrm{BW}_{8}$ and $\mathrm{BW}_{12}$ at $\mathrm{G}_{4}$. Also, $\mathrm{BC}$ represented high estimates of $h^{2}$ among the ages and generations ranged between 0.32 for $\mathrm{BC}_{12}$ at $\mathrm{G}_{5}$ and 0.69 for $\mathrm{BC}_{12}$ at $\mathrm{G}_{0}$. Moreover, high 


\section{N.G. Boutrous}

estimates of $h^{2}$ for BD were recorded among all ages and generations ranged between 0.31 for $\mathrm{G}_{3}$ at $\mathrm{BD}_{12}$ to 0.67 for $\mathrm{BD}_{25}$ at $\mathrm{G}_{4}$. Highest estimates of $h^{2}$ for $\mathrm{BL}_{12}$ were detected at $\mathrm{G}_{5}(0.88)$, while the lowest one was observed for $\mathrm{BL}_{12}$ at $\mathrm{G}_{4}(0.26)$. Low values of $h^{2}$ for fertility and hatchability were detected among all experimental generations ranged between 0.02 to 0.14 for fertility and between 0.02 to 0.05 for hatchability among the studied six generations. It could be concluded from the formentioned results that selection for breast circumferences in the coming generations will be useless due to the decrease of heritability for this trait with the subsequent selection.

Same conclusions of heritability for body weight at different ages were reported by Ragaa and Ashour (2014) on EL-Salam chicken strain and by Ebegbulem and Okon (2018) on Guinea chicken. Also, the trait of selection in this study $\left(\mathrm{BC}_{12}\right)$ was decreased with the subsequent selection upon the advanced generations. The high estimates of heritability for BC in this study are in accordance with those previously reported after selection by Abdellatif (1999) and EL-Wardany (1999). Other studied parameters such as $\mathrm{BD}$ and $\mathrm{BL}$ were generallyrepresent increase upon selected generations and highest estimates of heritability were recorded for $\mathrm{G}_{5}$. The low heritability values for fertility and hatchability among the studied generations justify the need for indirect selection for improving these traits. These low estimates of heritability can be explained by high environmental effect on these traits and additional information is required from relatives to improve these traits (Gebriel et al., 2009). The low estimates of recorded heritability for fertility and hatchability in the current study were similar to literature estimates by Sapp et al. (2004). Ragaa and Ashour (2014) mentioned that heritability of $\mathrm{BL}_{12}$ for EL-Salam chicken strain was 0.84. Genetic correlations between fertility with some body male measurements through six selected generations for breast circumference are shown in Table $4 \mathrm{It}$ appears from data of this table that values of genetic correlations between fertility and body weights among the studied generations were low differed between 0.10 up to 0.34 with value of 0.28 for $\mathrm{BW}_{1}$ at $\mathrm{G}_{5}$. The genetic correlation values of fertility with $\mathrm{BC}$ presented increase from $0.05,0.16$ and 0.18 in $\mathrm{G}_{0}$ to $0.30,0.45$ and 0.32 in $\mathrm{G}_{5}$ for $\mathrm{BC}_{12}, \mathrm{BC}_{25}$ and $\mathrm{BC}_{45}$, respectively. Also, $\mathrm{BD}_{45}$ represented high values of genetic correlations with fertility among $G_{2}, G_{4}$ and $G_{5}$ generations being $0.48,0.60$ and 0.87 , respectively. Fertility had positive genetic correlations with $\mathrm{BL}_{12}, \mathrm{BL}_{25}$ and $\mathrm{BL}_{45}$ but among the last three generations of selection $\left(\mathrm{G}_{3}, \mathrm{G}_{4}\right.$ and $\mathrm{G}_{5}$ ) were negative except $\mathrm{BL}_{12}$ at $\mathrm{G}_{4}$. Genetic correlations between hatchability of fertile eggs with some body male measurements and fertility through six selected generations for breast GM circumference are shown in Table 5 Genetic correlations for hatchability of fertile eggs represented high values with $\mathrm{BC}_{12}$ in $\mathrm{G}_{2}$ and $\mathrm{G}_{3}$ besides moderate correlations of $B C$ in $G_{4}$ and $G_{5}$. Third generation represented negative correlations between hatchability with $\mathrm{BW}_{1}$ and $\mathrm{BD}$ at 12,25 and 45 weeks of age. Furthermore, high positive values of genetic correlation were observed between hatchability and $\mathrm{BL}_{12}$ at the last four generation of selection. The same trend of increasing values were almost similar at $\mathrm{BL}_{25}$, for $\mathrm{G}_{2}$ and $\mathrm{G}_{3}$. While, $\mathrm{BL}_{45}$ represented negative genetic correlations among $\mathrm{G}_{0}, \mathrm{G}_{3}$ and $\mathrm{G}_{5}$. The genetic correlations between hatchability and 
Chickens- Selection - Heritability- Fertility - Breast

fertility were varied between low and moderate throughout the selected generations.

The low values of genetic correlation between fertility and hatchability with weights among the generations were previously confirmed by Ashour et al. (2015), while Cavero and Schmutz (2009) found negative correlation between the mentioned traits. Also, Siegel and Dunnington (1985) found that selection for traits such as growth rate and body measurements have been negatively association with reproduction traits. Ruth (2002) mentioned that external characteristic of keel length and chest width of male broiler breeders have been proposed as method of evaluation reproductive potential. Opposite results were obtained by Salahi et al. (2014) who referred thatmales with a good balance of keel length and breast width had a high fertility rate. Different authors reported that high body weight for males leads to leg and foot problems and may have trouble mating and consequently affect fertility by(Brillard,2003, Gao et al., 2010 and Salahiet al., 2014).
The positive values of the estimated correlation between fertility and hatchability of fertile eggs are in good agreement with Beaumont et al.(1997). selection for body circumferences and consequently body weight should be done with care for obtaining high levels of fertility during the generations selection.

It is concluded from the present results that selection for breast circumferences should be substituted with other body measurements such as BD or BL for Gimmizah flock in the coming generations and fertility reduction should be taken into consideration in the genetic selection 


\begin{tabular}{|c|c|c|c|c|c|c|c|c|}
\hline \multicolumn{3}{|c|}{ Generation $(\mathrm{G}) \quad$ Traits } & $\mathrm{G}_{0}$ & $\mathrm{G}_{1}$ & $\mathrm{G}_{2}$ & $\mathrm{G}_{3}$ & $\mathrm{G}_{4}$ & $\mathrm{G}_{5}$ \\
\hline \multirow{9}{*}{ 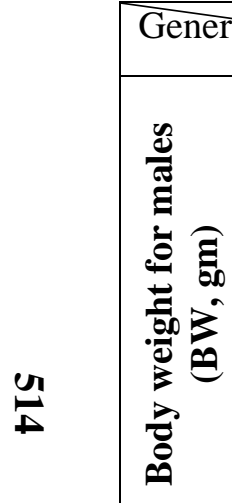 } & BW1 Day & Selected & $37.61 \pm 0.06^{\mathrm{Ad}}$ & $39.09 \pm 0.07^{\text {a }}$ & $38.59 \pm 0.12^{b}$ & $38.81 \pm 0.26^{\mathrm{b}}$ & $37.76 \pm 0.09^{\mathrm{Ac}}$ & $38.11 \pm 0.19^{\mathrm{Ac}}$ \\
\hline & 1(1Day) & Control & $36.97 \pm 0.09^{\mathrm{Bd}}$ & $39.00 \pm 0.03^{\mathrm{a}}$ & $38.59 \pm 0.09^{\mathrm{b}}$ & $38.17 \pm 0.20^{\mathrm{c}}$ & $34.73 \pm 0.04^{\mathrm{Be}}$ & $33.67 \pm 0.11^{\mathrm{Bf}}$ \\
\hline & BW8 & Selected & $650.37 \pm 1.40^{\mathrm{Ae}}$ & $677.71 \pm 2.05^{\mathrm{c}}$ & $669.90 \pm 2.13^{\mathrm{d}}$ & $624.28 \pm 6.49^{\mathrm{Af}}$ & $709.45 \pm 2.26^{\mathrm{Ab}}$ & $736.29 \pm 2.60^{\mathrm{Aa}}$ \\
\hline & $(8-w k)$ & Control & $617.07 \pm 2.62^{\mathrm{Bb}}$ & $664.00 \pm 1.65 \mathrm{a}$ & $664.0 \pm 0.02^{\mathrm{a}}$ & $539.21 \pm 5.02^{\mathrm{Bc}}$ & $536.43 \pm 2.64^{\mathrm{Bc}}$ & $501.67 \pm 2.91^{\mathrm{Bd}}$ \\
\hline & BW12 (12- & Selected & $1748.78 \pm 15.04^{\mathrm{Aa}}$ & $1202.5 \pm 5.18^{\mathrm{Ab}}$ & $1198.90 \pm 20.90^{b}$ & $1125.39 \pm 5.48^{\mathrm{c}}$ & $1187.39 \pm 4.97^{\mathrm{b}}$ & $1105.18 \pm 3.92^{\mathrm{Ac}}$ \\
\hline & wk) & Control & $1590.74 \pm 57.59^{\mathrm{Ba}}$ & $1174.16 \pm 6.10^{\mathrm{Bb}}$ & $1188.43 \pm 21.89^{b}$ & $1109.44 \pm 15.33^{\mathrm{c}}$ & $1183.0 \pm 3.50^{\mathrm{b}}$ & $1058.78 \pm 2.04^{\mathrm{B} \mathrm{d}}$ \\
\hline & BW25 (25- & Selected & $2411.74 \pm 14.15^{\text {Аa }}$ & $2432.22 \pm 21.26^{\mathrm{Aa}}$ & $1433.56 \pm 22.65^{\mathrm{Ab}}$ & $1431 \pm 5.80^{\mathrm{Ab}}$ & $1436.00 \pm 10.59 \mathrm{~b}$ & $1373.37 \pm 3.8^{c}$ \\
\hline & wk) & Control & $1937.95 \pm 50.53^{\mathrm{Ba}}$ & $1905.75 \pm 17.76^{\mathrm{Ba}}$ & $1305.0 \pm 20.15^{\text {Bd }}$ & $1324.04 \pm 8.13^{\mathrm{Bd}}$ & $1435.00 \pm 8.10^{\mathrm{b}}$ & $1386.82 \pm 16.82^{\mathrm{c}}$ \\
\hline & BW45 (45- & Selected & $2514.20 \pm 36.01^{\mathrm{Ac}}$ & $2503 \pm 10.05^{\mathrm{Ae}}$ & $2593.94 \pm 16.83^{\mathrm{Ab}}$ & $2642.67 \pm 22.44^{\mathrm{Ad}}$ & $2775.15 \pm 14.3^{\mathrm{Ad}}$ & $2891.85 \pm 12.03^{\mathrm{Aa}}$ \\
\hline & wk) & Control & $2079.73 \pm 34.61^{\text {B d }}$ & $2309.20 \pm 12.50^{\mathrm{Bb}}$ & $2253.22 \pm 36.24^{\mathrm{Ba}}$ & $2215.00 \pm 20.51^{\mathrm{Bc}}$ & $2255.00 \pm 0.15^{\mathrm{Bc}}$ & $2357.08 \pm 73.41^{\text {Bab }}$ \\
\hline & BC12 (12- & Selected & $27.92 \pm 0.03^{\mathrm{Ac}}$ & $28.51 \pm 0.05^{b}$ & $28.32 \pm 0.03^{\mathrm{Ab}}$ & $26.59 \pm 0.09^{\mathrm{Ad}}$ & $27.79 \pm 0.05^{\mathrm{Ac}}$ & $31.81 \pm 0.22^{\mathrm{Aa}}$ \\
\hline- & wk) & Control & $27.31 \pm 0.17^{\text {Babc }}$ & $28.50 \pm 0.05^{\mathrm{a}}$ & $28.02 \pm 0.10^{\mathrm{Bab}}$ & $26.15 \pm 0.18^{\mathrm{Bc}}$ & $26.80 \pm 0.08^{\mathrm{Bbc}}$ & $24.27 \pm 1.07^{\mathrm{Bd}}$ \\
\hline$\vec{g}$ & BC25 (25- & Selected & $28.38 \pm 0.03^{\mathrm{Ae}}$ & $29.91 \pm 0.03^{\mathrm{Ad}}$ & $31.47 \pm 0.04^{\mathrm{Ac}}$ & $28.94 \pm 0.14^{\mathrm{A}} \mathrm{f}$ & $35.44 \pm 0.13^{\mathrm{Ab}}$ & $35.95 \pm 0.07^{\mathrm{Aa}}$ \\
\hline$\Xi$ & wk) & Control & $27.29 \pm 0.08^{\mathrm{Bc}}$ & $29.10 \pm 0.02^{\mathrm{Bb}}$ & $29.13 \pm 0.96^{\mathrm{Bb}}$ & $26.00 \pm 0.09^{\mathrm{Bd}}$ & $33.39 \pm 0.14^{\mathrm{Ba}}$ & $33.88 \pm 0.21^{\mathrm{Ba}}$ \\
\hline & BC45 (45- & Selected & $32.70 \pm 0.12 \mathrm{Ad}$ & $32.15 \pm 0.07^{\mathrm{Ae}}$ & $32.26 \pm 0.09^{\mathrm{e}}$ & $33.83 \pm 0.14 \mathrm{Ac}$ & $36.60 \pm 0.02^{\mathrm{Ab}}$ & $38.06 \pm 0.11 \mathrm{Aa}$ \\
\hline & wk) & Control & $31.97 \pm 0.11^{\mathrm{B} \mathrm{c}}$ & $30.50 \pm 0.03^{\mathrm{Bd}}$ & $32.13 \pm 0.09^{\mathrm{c}}$ & $29.20 \pm 0.08^{\mathrm{Be}}$ & $34.20 \pm 11^{\mathrm{Bb}}$ & $36.91 \pm 0.64^{\mathrm{Ba}}$ \\
\hline
\end{tabular}

Table(1): Means \pm SE. of some body male measurements and hatchability of Gimmizah chickens selected for breast circumference among

six generations

To be continued 
Continue Table (1):

\begin{tabular}{|c|c|c|c|c|c|c|c|c|}
\hline \multirow{6}{*}{ 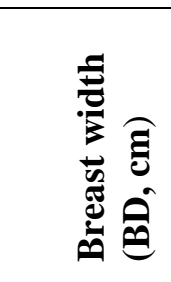 } & \multirow{6}{*}{$\begin{array}{l}\text { BD12(12- } \\
\text { wk) } \\
\text { BD25(25- } \\
\text { wk) } \\
\text { BD45(45- } \\
\text { wk) }\end{array}$} & \multirow{2}{*}{$\begin{array}{l}\text { Selected } \\
\text { Control }\end{array}$} & $3.51 \pm 0.03^{\mathrm{e}}$ & $4.05 \pm 0.02^{\mathrm{Ac}}$ & $4.09 \pm 0.02^{\mathrm{Ac}}$ & $4.92 \pm 0.05^{\mathrm{Ad}}$ & $5.30 \pm 0.02^{\mathrm{Ab}}$ & $5.95 \pm 0.03^{\mathrm{Aa}}$ \\
\hline & & & $3.35 \pm 0.03^{\mathrm{c}}$ & $3.50 \pm 0.01^{\mathrm{Bc}}$ & $3.57 \pm 0.01^{\mathrm{Bc}}$ & $3.84 \pm 0.03^{\mathrm{Bb}}$ & $4.902 \pm 0.01^{\mathrm{Ba}}$ & $4.92 \pm 0.07^{\mathrm{Ba}}$ \\
\hline & & Selected & $5.82 \pm 0.02^{\mathrm{Ab}}$ & $4.90 \pm 0.01^{\mathrm{e}}$ & $5.45 \pm 0.03^{\mathrm{Ac}}$ & $5.35 \pm 0.08^{\mathrm{Ad}}$ & $6.73 \pm 0.04^{\mathrm{Ab}}$ & $7.29 \pm 0.04^{\mathrm{Aa}}$ \\
\hline & & Control & $5.37 \pm 0.08^{\mathrm{B} \mathrm{c}}$ & $4.90 \pm 0.01^{\mathrm{de}}$ & $5.15 \pm 0.01^{\mathrm{Bdc}}$ & $4.70 \pm 0.0^{\mathrm{Be}}$ & $5.16 \pm 0.04^{\mathrm{Bb}}$ & $6.69+0.13^{\mathrm{Ba}}$ \\
\hline & & Selected & $5.88 \pm 0.01^{\mathrm{Ac}}$ & $5.76 \pm 0.02^{\mathrm{Ad}}$ & $6.01 \pm 0.02^{\mathrm{b}}$ & $5.90 \pm 0.07^{\mathrm{Ac}}$ & $5.98 \pm 0.02^{\mathrm{Ac}}$ & $8.80+0.06^{\mathrm{Aa}}$ \\
\hline & & Control & $5.69 \pm 0.10^{\mathrm{Bb}}$ & $5.20 \pm 0.01^{\mathrm{Bc}}$ & $6.01 \pm 0.06^{\mathrm{b}}$ & $5.30 \pm 0.07^{\mathrm{Bc}}$ & $5.60 \pm 0.02^{\mathrm{Bb}}$ & $7.73+0.23^{\mathrm{Ba}}$ \\
\hline \multirow{6}{*}{ 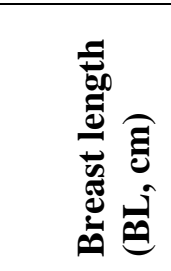 } & BL12(12- & Selected & $12.52 \pm 0.09^{\mathrm{Ad}}$ & $13.57 \pm 0.02^{\mathrm{b}}$ & $13.52 \pm 0.03^{\mathrm{b}}$ & $12.28 \pm 0.09^{\mathrm{Be}}$ & $12.66 \pm 0.02^{\mathrm{Ac}}$ & $14.32+0.09^{\mathrm{Aa}}$ \\
\hline & & Control & $12.05 \pm 0.01^{\mathrm{Bb}}$ & $13.60 \pm 0.02^{\mathrm{a}}$ & $13.39 \pm 0.04^{\mathrm{a}}$ & $12.74 \pm 0.10^{\mathrm{Aa}}$ & $11.33 \pm 0.02^{\mathrm{Bc}}$ & $11.09+0.45^{\mathrm{Bc}}$ \\
\hline & BL25(25- & Selected & $13.54 \pm 0.01^{\mathrm{Ae}}$ & $13.01 \pm 0.02^{\mathrm{f}}$ & $14.20 \pm 0.02^{\mathrm{Ac}}$ & $13.98 \pm 0.06^{\mathrm{Ad}}$ & $15.30 \pm 0.04^{\mathrm{b}}$ & $15.19+0.05^{\mathrm{Aa}}$ \\
\hline & & Control & $13.01 \pm 0.05^{\mathrm{B} \mathrm{c}}$ & $13.0 \pm 0.01^{\mathrm{c}}$ & $13.97 \pm 0.01^{\mathrm{Bb}}$ & $12.10 \pm 0.0^{\mathrm{Bd}}$ & $13.28 \pm 0.03^{\mathrm{a}}$ & $13.62+0.17^{\mathrm{Ba}}$ \\
\hline & BL4 & ted & $13.80 \pm 0.20^{\mathrm{Ae}}$ & $14.32 \pm 0.03^{\mathrm{Ad}}$ & $14.40 \pm 0.04^{\mathrm{Ad}}$ & $14.90 \pm 0.06^{\mathrm{Ac}}$ & $16.38 \pm 0.05^{\mathrm{b}}$ & $17.11+0.04^{\mathrm{Aa}}$ \\
\hline & wk) & $\mathrm{Co}$ & $13.00 \pm 0.05^{\mathrm{Bc}}$ & $12.0 \pm 0.03^{\mathrm{Bd}}$ & $13.84 \pm 0.08^{\mathrm{Bb}}$ & $14.10 \pm 0.06^{\mathrm{Bb}}$ & $\pm 0.05^{\mathrm{a}}$ & $16.67+0.29^{\mathrm{Ba}}$ \\
\hline \multicolumn{2}{|l|}{ Fertility\% } & Selected & $90.77 \pm 1.09^{f}$ & $93.98 \pm 0.87^{\mathrm{e}}$ & $95.51 \pm 0.55^{\text {Ad }}$ & $97.18 \pm 1.03^{\mathrm{Ac}}$ & $97.40 \pm 1.30^{\mathrm{Ab}}$ & $98.53 \pm 1.11^{\mathrm{Aa}}$ \\
\hline & & $\mathrm{C}$ & 90.08 & 93.50 & $93.20 \pm 1.47^{\mathrm{Bc}}$ & $94.44 \pm 3.15^{\mathrm{Ba}}$ & $91.60 \pm 3.81^{\mathrm{Bd}}$ & $94.41 \pm 2.19^{\mathrm{Ba}}$ \\
\hline \multirow{2}{*}{\multicolumn{2}{|c|}{$\begin{array}{l}\text { Hatchability } \\
\text { Of fertile eggs\% }\end{array}$}} & Selected & $91.18 \pm 0.23^{\mathrm{c}}$ & $90.50 \pm 1.07^{\mathrm{d}}$ & $92.52 \pm 0.14^{\mathrm{Ab}}$ & $91.42 \pm 2.28^{\mathrm{Ab}}$ & $91.27 \pm 0.28^{\mathrm{c}}$ & $94.82 \pm 1.77^{\mathrm{Aa}}$ \\
\hline & & Control & $90.01 \pm 0.57^{\mathrm{b}}$ & $90.15 \pm 3.84^{b}$ & $90.44 \pm 0.38^{\mathrm{Bb}}$ & $90.19 \pm 4.77^{\mathrm{Bb}}$ & $90.26 \pm 0.78^{b}$ & $91.22 \pm 3.25^{\mathrm{Ba}}$ \\
\hline
\end{tabular}

A, B Means in the same column within each trait with different superscripts are significantly different $(p<0.05)$

$\mathrm{a}, .$. and $\mathrm{f}$ means in the same row among generations with different superscripts are significantly different $(\mathrm{p}<0.05)$ 
Table (2): Genetic additive estimates \pm standard errors $\left(\mathrm{V}_{\mathrm{A}} \pm \mathrm{SE}\right)$ of some body male measurements and hatchability for Gimmizah chickens selected for breast circumference among six generations

\begin{tabular}{|c|c|c|c|c|c|c|c|}
\hline \multicolumn{2}{|c|}{$\begin{array}{rr} & \text { Generations } \\
\text { Traits }\end{array}$} & $\mathbf{G}_{\mathbf{0}}$ & $\mathbf{G}_{1}$ & $\mathbf{G}_{2}$ & $\mathbf{G}_{3}$ & $\mathbf{G}_{4}$ & $\mathbf{G}_{5}$ \\
\hline \multirow{6}{*}{$\begin{array}{l}\text { Body weight for males } \\
\text { (BW) }\end{array}$} & Body weight for males & $\mathrm{NE}$ & $1.63 \pm 0.48$ & $0.84 \pm 0.77$ & $13.66 \pm 8.60$ & $14.80 \pm 13.7$ & $2.51 \pm 0.50$ \\
\hline & BW1 at day 1 & & & & & & \\
\hline & BW8 at 8-wk & $13.9 \pm 12.6$ & $1.17 \pm 0.35$ & $1.08 \pm 0.21$ & $46.38 \pm 2.3$ & $13.9 \pm 12.6$ & $18.14 \pm 0.83$ \\
\hline & BW12 at $12-w k$ & $13.9 \pm 12.6$ & $1.08 \pm 0.74$ & $1.16 \pm 0.08$ & $1.08 \pm 0.29$ & $13.90 \pm 12.7$ & $1.02 \pm 0.24$ \\
\hline & BW25 at $25-w k$ & $6.65 \pm 0.52$ & $1.02 \pm 0.20$ & $1.08 \pm 0.19$ & $1.08 \pm 0.37$ & $1.01 \pm 0.61$ & $1.02 \pm 0.21$ \\
\hline & BW45 at 45-wk & $1.0 \pm 0.10$ & $1.21 \pm 0.16$ & $1.01 \pm 0.42$ & $1.03 \pm 0.22$ & $1.01 \pm 0.10$ & $1.03 \pm 0.27$ \\
\hline \multirow{3}{*}{$\begin{array}{l}\text { Breast circumference } \\
\text { (BC) }\end{array}$} & BC12 at 12-wk & $0.206 \pm 0.04$ & $0.14 \pm 0.09$ & $1.02 \pm 0.18$ & $1.42 \pm 0.26$ & $0.62 \pm 0.76$ & $1.02 \pm 0.21$ \\
\hline & $\mathrm{BC} 25$ at $25-\mathrm{wk}$ & $0.12 \pm 0.05$ & $1.01 \pm 0.21$ & $1.95 \pm 0.46$ & $16.10 \pm 2.66$ & $39.98 \pm 4.7$ & $1.58 \pm 0.47$ \\
\hline & BC45 at $45-w k$ & $1.0 \pm 0.61$ & $\mathrm{NE}$ & $1.01 \pm 0.42$ & $1.08 \pm 0.52$ & $3.94 \pm 0.16$ & $1.62 \pm 0.39$ \\
\hline \multirow{4}{*}{$\begin{array}{l}\text { Breast width } \\
\text { (BD) }\end{array}$} & BD12 at 12-wk & $\mathrm{NE}$ & $\mathrm{NE}$ & $1.02 \pm 0.18$ & $1.02 \pm 0.26$ & $\mathrm{NE}$ & $1.58 \pm 0.45$ \\
\hline & BD25 at 25-wk & $\mathrm{NE}$ & $1.01 \pm 0.20$ & $1.01 \pm 0.86$ & $1.08 \pm 0.51$ & $0.11 \pm 0.06$ & $0.30 \pm 0.12$ \\
\hline & BD45 at 45-wk & $1.0 \pm 0.40$ & $0.49 \pm 0.23$ & $1.09 \pm 0.09$ & $1.08 \pm 0.51$ & $1.09 \pm 0.15$ & $1.02 \pm 0.32$ \\
\hline & BL12 at 12-wk & $0.136 \pm 0.04$ & $0.20 \pm 0.11$ & $1.02 \pm 0.18$ & $1.01 \pm 0.26$ & $4.56 \pm 7.41$ & $1.90 \pm 0.44$ \\
\hline \multirow{2}{*}{$\begin{array}{l}\text { Breast length } \\
\text { (BL) }\end{array}$} & BL25 at 25-wk & $\mathrm{NE}$ & $1.01 \pm 0.20$ & $1.01 \pm 0.87$ & $1.08 \pm 0.51$ & $17.88 \pm 3.04$ & $0.49 \pm 0.18$ \\
\hline & BL45 at $45-w k$ & $1.0 \pm 0.42$ & $0.15 \pm 0.06$ & $1.01 \pm 0.52$ & $1.08 \pm 0.51$ & $2.67 \pm 0.12$ & $0.43 \pm 0.28$ \\
\hline \multirow{2}{*}{\multicolumn{2}{|c|}{$\begin{array}{l}\text { Fertility \% } \\
\text { Hatchability of fertile eggs\% }\end{array}$}} & $\mathrm{NE}$ & $.84 \pm 0.43$ & $1.18 \pm 2.42$ & $0.51 \pm 0.11$ & $1.85 \pm 0.52$ & $1.83 \pm 0.42$ \\
\hline & & $\mathrm{NE}$ & $1.40 \pm 0.24$ & $1.79 \pm 0.48$ & $32.37 \pm 6.98$ & $1.36 \pm 0.33$ & $1.92 \pm 0.24$ \\
\hline
\end{tabular}

NE : Non- estimable 
Table(3): Heritability estimates \pm standard errors $\left(h^{2} \pm S E\right)$ of some body male measurements and hatchability for Gimmizah chickens selected for breast circumference among six generations

\begin{tabular}{|c|c|c|c|c|c|c|c|}
\hline Traits & Generations & $\mathbf{G}_{\mathbf{0}}$ & $\mathbf{G}_{1}$ & $\mathbf{G}_{2}$ & $\mathbf{G}_{3}$ & $\mathbf{G}_{\mathbf{4}}$ & $\mathbf{G}_{5}$ \\
\hline \multirow{5}{*}{$\begin{array}{l}\text { Body weight for males } \\
\text { (BW) }\end{array}$} & BW1 at day 1 & $\mathrm{NE}$ & $0.65 \pm 0.15$ & $0.65 \pm 0.30$ & $0.60 \pm 0.24$ & $0.62 \pm 0.09$ & $0.61 \pm 0.08$ \\
\hline & BW8 at 8-wk & $0.68 \pm 0.06$ & $0.50 \pm 0.01$ & $0.50 \pm 0.01$ & $0.50 \pm 0.01$ & $0.97 \pm 0.06$ & $0.51 \pm 0.01$ \\
\hline & BW12 at $12-w k$ & $0.68 \pm 0.06$ & $0.50 \pm 0.01$ & $0.50 \pm 0.01$ & $0.50 \pm 0.01$ & $0.97 \pm 0.06$ & $0.50 \pm 0.01$ \\
\hline & BW25 at $25-w k$ & $0.65 \pm 0.01$ & $0.50 \pm 0.01$ & $0.50 \pm 0.01$ & $0.50 \pm 0.01$ & $0.50 \pm 0.01$ & $0.50 \pm 0.01$ \\
\hline & BW45 at $45-w k$ & $0.50 \pm 0.06$ & $\mathrm{NE}$ & $0.50 \pm 0.01$ & $0.50 \pm 0.01$ & $0.50 \pm 0.01$ & $0.50 \pm 0.01$ \\
\hline \multirow{4}{*}{$\begin{array}{l}\text { Breast circumference } \\
\text { (BC) }\end{array}$} & $\mathrm{BC} 12$ at $12-\mathrm{wk}$ & $0.69 \pm 0.11$ & $0.56 \pm 0.09$ & $0.40 \pm 0.02$ & $0.48 \pm 0.01$ & $0.49 \pm 0.09$ & $0.32 \pm 0.07$ \\
\hline & $\mathrm{BC} 25$ at $25-\mathrm{wk}$ & $\mathrm{NE}$ & $0.50 \pm 0.01$ & $0.50 \pm 0.01$ & $0.50 \pm 0.01$ & $0.35 \pm 0.01$ & $0.67 \pm 0.14$ \\
\hline & BC45 at 45-wk & $0.50 \pm 0.07$ & $\mathrm{NE}$ & $0.50 \pm 0.01$ & $0.50 \pm 0.01$ & $0.58 \pm 0.02$ & $0.68 \pm 0.13$ \\
\hline & BD12 at 12-wk & $\mathrm{NE}$ & $\mathrm{NE}$ & $0.50 \pm 0.01$ & $0.31 \pm 0.07$ & $\mathrm{NE}$ & $0.05 \pm 0.03$ \\
\hline \multirow{3}{*}{$\begin{array}{l}\text { Breast width } \\
\text { (BD) }\end{array}$} & BD25 at 25-wk & $\mathrm{NE}$ & $0.50 \pm 0.01$ & $0.50 \pm 0.01$ & $0.50 \pm 0.01$ & $0.50 \pm 0.01$ & $0.67 \pm 0.14$ \\
\hline & BD45 at 45-wk & $0.50 \pm 0.07$ & $0.63 \pm 0.01$ & $0.32 \pm 0.02$ & $0.61 \pm 0.09$ & $0.65 \pm 0.09$ & $0.50 \pm 0.01$ \\
\hline & BL12 at 12-wk & $0.79 \pm 0.15$ & $0.73 \pm 0.31$ & $0.71 \pm 0.22$ & $0.76 \pm 0.18$ & $0.26 \pm 0.12$ & $0.88 \pm 0.03$ \\
\hline \multirow{2}{*}{$\begin{array}{l}\text { Breast length } \\
\text { (BL) }\end{array}$} & BL25 at 25-wk & $0.50 \pm 0.06$ & $0.73 \pm 0.015$ & $0.65 \pm 0.21$ & $0.72 \pm 0.23$ & $0.72 \pm 0.04$ & $0.69 \pm 0.23$ \\
\hline & BL45 at $45-w k$ & $0.50 \pm 0.06$ & $0.73 \pm 0.015$ & $0.65 \pm 0.21$ & $0.72 \pm 0.23$ & $0.72 \pm 0.04$ & $0.69 \pm 0.23$ \\
\hline \multirow{2}{*}{\multicolumn{2}{|c|}{$\begin{array}{l}\text { Fertility \% } \\
\text { Hatchabilityof fertile eggs \% }\end{array}$}} & $\mathrm{NE}$ & $0.14 \pm 0.08$ & $0.024 \pm 0.07$ & $0.02 \pm 0.01$ & $0.050 \pm 0.01$ & $0.048 \pm 0.08$ \\
\hline & & $\mathrm{NE}$ & $0.048 \pm 0.08$ & $0.050 \pm 0.01$ & $0.02 \pm 0.01$ & $0.050 \pm 0.01$ & $0.049 \pm 0.04$ \\
\hline
\end{tabular}

NE :Non- estimable 
Table (4): Genetic correlations between fertility andsome body male measurements of Gimmizah chickens selected for breast circumference among six generations

\begin{tabular}{|c|c|c|c|c|c|c|c|}
\hline Traits & Generations & $\mathbf{G}_{\mathbf{0}}$ & $\mathbf{G}_{1}$ & $\mathbf{G}_{2}$ & $\mathbf{G}_{3}$ & $\mathbf{G}_{4}$ & $\mathbf{G}_{5}$ \\
\hline $\begin{array}{l}\text { Body weight for males } \\
\text { (BW) } \\
\text { Breast circumference } \\
\text { (BC) } \\
\text { Breast width } \\
\text { (BD) } \\
\text { Breast length } \\
\text { (BL) }\end{array}$ & $\begin{array}{l}\text { BW1 at day } 1 \\
\text { BW8 at } 8-w k \\
\text { BW12 at } 12-w k \\
\text { BW25 at } 25-w k \\
\text { BW45 at } 45-w k \\
\text { BC12 at } 12-w k \\
\text { BC25 at } 25-w k \\
\text { BC45 at } 45-w k \\
\text { BD12 at } 12-w k \\
\text { BD25 at } 25-w k \\
\text { BD45 at } 45-w k \\
\text { BL12 at } 12-w k \\
\text { BL25 at } 25-w k \\
\text { BL45 at } 45-w k\end{array}$ & $\begin{array}{l}0.34 \pm 0.02 \\
0.10 \pm 0.01 \\
0.10 \pm 0.01 \\
0.10 \pm 0.01 \\
0.10 \pm 0.01 \\
0.05 \pm 0.01 \\
0.16 \pm 0.03 \\
0.18 \pm 0.03 \\
0.44 \pm 0.01 \\
0.20 \pm 0.01\end{array}$ & $\begin{array}{l}0.16 \pm 0.04 \\
0.10 \pm 0.01 \\
0.10 \pm 0.01 \\
0.10 \pm 0.01 \\
0.10 \pm 0.01 \\
0.15 \pm 0.03 \\
0.14 \pm 0.05 \\
0.25 \pm 0.06 \\
0.19 \pm 0.08 \\
0.25 \pm 0.06 \\
0.02 \pm 0.01 \\
0.17 \pm 0.10 \\
0.40 \pm 0.18\end{array}$ & $\begin{array}{l}0.10 \pm 0.01 \\
0.10 \pm 0.01 \\
0.10 \pm 0.01 \\
0.10 \pm 0.01 \\
0.14 \pm 0.01 \\
0.12 \pm 0.02 \\
0.08 \pm 0.01 \\
0.65 \pm 0.01 \\
0.29 \pm 0.03 \\
0.48 \pm 0.21 \\
0.37 \pm 0.01 \\
0.53 \pm 0.20 \\
0.98 \pm 0.03\end{array}$ & $\begin{array}{l}0.13 \pm 0.03 \\
0.10 \pm 0.02 \\
0.10 \pm 0.01 \\
0.10 \pm 0.01 \\
0.10 \pm 0.01 \\
0.80 \pm 0.20 \\
0.98 \pm 0.01 \\
0.15 \pm 0.07 \\
0.41 \pm 0.01 \\
0.10 \pm 0.01 \\
0.14 \pm 0.06 \\
0.55 \pm 0.01 \\
0.37 \pm 0.09 \\
0.81 \pm 0.15\end{array}$ & $\begin{array}{l}0.06 \pm 0.02 \\
0.10 \pm 0.01 \\
0.10 \pm 0.01 \\
0.10 \pm 0.01 \\
0.10 \pm 0.01 \\
0.10 \pm 0.01 \\
0.28 \pm 0.08 \\
0.13 \pm 0.02 \\
0.29 \pm 0.07 \\
0.60 \pm 0.20 \\
0.17 \pm 0.02 \\
0.76 \pm 0.18 \\
0.20 \pm 0.08\end{array}$ & $\begin{array}{l}0.28 \pm 0.03 \\
0.10 \pm 0.01 \\
0.10 \pm 0.01 \\
0.10 \pm 0.01 \\
0.10 \pm 0.01 \\
0.30 \pm 0.01 \\
0.45 \pm 0.21 \\
0.32 \pm 0.11 \\
0.78 \pm 0.15 \\
0.10 \pm 0.01 \\
0.87 \pm 0.21 \\
0.50 \pm 0.14 \\
0.15 \pm 0.07 \\
0.19 \pm 0.03\end{array}$ \\
\hline
\end{tabular}


Table(5): Genetic correlations between hatchability with some body male measurements and fertility for Gimmizah chickens selected for breast circumference among six generations

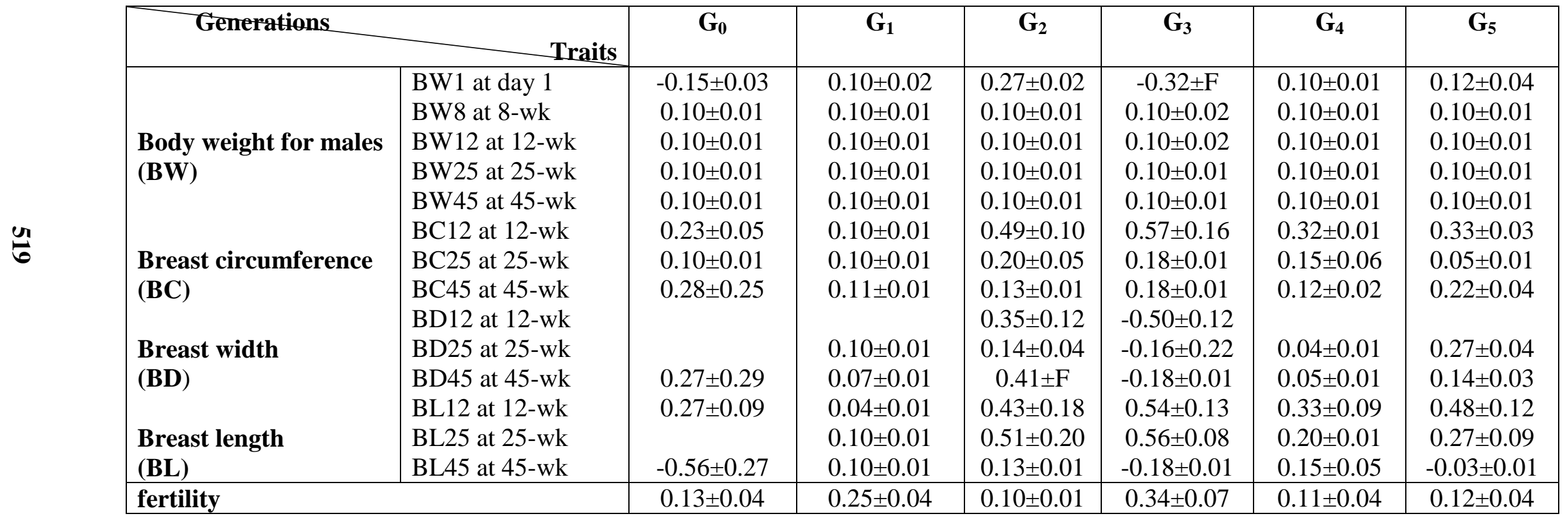




\section{REFERENCES}

Abdellatif, M. A. 1999. Selection for body weight at eight weeks of age in Dandarawi chicken. 1-Direct and correlated responses in growth measurements. Egypt. Poult. Sci., 19: 35-52.

Abou El-Ghar, R. Sh.; and Ragaa, A. E. K. 2016. Effect of early selection for body weight, keel length and breast circumference on egg production traits in Inshas strain of chickens. Egypt. Poult. Sci. 36: 375-387.

Ashour, A. F.; Badwi, Y. K.; and Ragaa A. E. K. 2015. Effect of selection for body weight on egg production, egg quality, fertility and hatchability traits in El-Salam chicken strain in Egypt. Anim. And poult. prod., Mansoura Univ., 6: 781-796.

Ayman E. T.; Fawzy, A.; and Abd El-Ghany. 2013.Improving production traits for El-Salamand Mandarah chicken strains by crossingii-estimation of crossbreeding effects on eggproduction and egg quality traits. International Scholarly and Scientific Research and Innovation., 7: 982-987.

Barbato, G. F.; Siegel, P. B.; and Cherry, J. A. 1983. Inheritance of body weight and associated traits in young chickens. Z. Tierz. Zuchtungsbiol. 100:350-363.

Beaumont, C.; Millet ,N.; Le BihanDuval, E.; Kipi, A.; and Dupuy, V. 1997. Genetic parameters of survival to the differentstages of embryonic death in laying hens. Poult. Sci.76:1193-1196.

Boldman, K. G.; Kriese, L. A.; Van Vleck, L. D.;Van Tassel, C. P.; and Kachman, S. D. 1995. A manual for use of MTDFREML. A set of programs to obtain estimates of variance andcovariance. ARS, USDA, Clay Center, NE.

Brillard, J. P. 2003. Practical aspects of fertility in poultry. World Poult Sci. J. 59:441-446.

Brillard, J. P. 2004. Natural mating in broiler breeders: present andfuture concerns. World Poult. Sci. J. 60:439445.

Carte, I. F.; and Leighton,A. T. 1969. Mating behavior andfertility in the large white turkey. Poult. Sci. 48:104114.

Cavero, D.; and Schmutz, M. 2009. Relationship between egg quality traits and hatchability in pure-line white layer strains. World Poultry Science Association. Proceedings of the $19^{\text {th }}$ European Symposium on Quality of Poultry Meat, 13th European Symposium on the Quality of Eggs and Egg Products. Turku, Finland, 1-7.

Dudgeon, J. S. 2010. Breeder Male Management. ImportantManagement Points to Ensure High Levels of Fertility and Hatchability. Newbridge, Scotland, UK: Aviagen, Ltd.

Duncan, D. B. 1955. Multiple range and multiple Ftests. Biometrics, 11: 1-42.

Dunnington, E. A.; and Siegel, P. B. 1985. Long-term selection for eightweek body weight in chickens -Direct and correlated responses. Theor. Appl. Genet.71:305-313.

Ebegbulem, V.N.; and Okon, B. 2018. Genetic parameter estimates of Guinea Fowl (NumidaMeleagris) in SouthSouth Region of Nigeria. J Ethol and Animal Sci., 1 :2-5.

El-Wardany, A. M. 1999. Influence of short-term selection of parents for body weight and some body measurements on I. Direct progeny 
Chickens- Selection - Heritability- Fertility - Breast

performance responses in local chickens. Egypt. Poult. Sci., 19: 255270.

Gao, Y.; Du Z. Q.; Feng, C.G.; Deng, X. M.; Li, N.; Da, Y.; and Hu, X. X. 2010. Identification of quantitative trait loci for shank length andgrowth at different development stages in chicken. Anim Genet. 41: 101-104.

Gebriel, G. M.; Kalamah, M. A.; ElFiky A. A.; and Ali, F. A. 2009. Some factors affecting semen quality traits in Norfa cocks. Egypt Poultry Sci. vol. 29: 677-693.

Gwaza, D. S.; Dim. N. I.; and Momoh, O. M. 2018. Effects of sire additive genetic variance on growth rate within and betweenpopulations of Nigerian local chicken ecotypes. J Res Rep Genet.2:1-5.

Merritt, E. S. 1958. Genetic and environmental effects on body measurements in broiler chickens. Dissertation Abstracts 18 :765 -766.

Meyer, K. 2006. WOMBAT - A program for mixed model analyses byrestricted maximum likelihood. User notes. Animal Genetics and Breeding Unit, Armidale, 83 pp.

Ogasawara, F. X.; H. Abplanalp.; and Asmundson,V. S. 1963. The effect of selection for body weight on reproduction inturkey hens. Poult. Sci. 42:838-842.

Ragaa, A.E. K.; and Ashour, A.F. 2014. Effect of selection for body weight on body measurements and carcass traits in El-Salam strain of chicken in egypt. Anim and Poult Prod., Mansoura Univ.5: 59461.

Ruth, H.M.2002. Reproduction in male broiler breeders. M.Sc. Thesis, TheUniversity of Georgia, Athens, GA.
Salahi, A.; Khabisi, M. M.; and Anissian, A. 2014. Effects of infectious bursal disease (IBD) on shank length and diameter, body weight andmortality in broiler breeder at rearing period., Turk I Vet Anim Sci. 38: 3439.

Sapp, R. L.; Rekaya, R.; Misztal, I.; and Wing. T. 2004. Male and female fertility and hatchability in chickens: A longitudinal mixed model approach. Poult. Sci., 83: 1253-1259.

SAS. 2010. SAS/STAT users guide. SAS Institute INC, Cary, nc27513, USA.

Schmidt, G. S.; Figueiredo, E. A. P.; and Ledur, M. C. 2006. Genetic gain for body weight, feed conversion and carcass traits in selected broiler strains. Braz. Poult. Sci., 8: 29-32.

Siegel, P. B.; and Dunnington, E. A. 1985. Reproductive complications associated with selection for broiler growth, Poultry Genetics and Breeding, edited by Hill W. G., Mason J. M., Hewitt D.Poultry genetics and breeding. Longman Group, Harlow, pp 59-72.

Sorensen, D. A.; and Kennedy, B. W. 1984. Estimation of geneticvariances from unselected and selected populations. J. Anim.Sci. 59:12131223.

Swayamprabha, N.; Shakti, K. D.; Prem, P. D.; Jaspreet, S. A.; Saroj, K. S.; Simarjeet, K.; Puneet, M.; and Baljinder, K. B. 2018. AIREML estimation of genetic parameters and study of factors affecting growth and fertility performance of sire line of IBL-80 broiler chicken. Indian J. Anim. Re. 53:1281-1286.

Teguia, A.; Ngandjou, H. M.; Defang, H.; and Tchoumboue, J. 2008. Study of the live bodyweight and body characteristics of the AfricanMuscovy 
N.G. Boutrous

Duck (Cairinamoschata). Trop. Anim.Health Prod., 40: 5-10.

Tongsiri, S.; Gilbert, M. J.; Susanne, H.; Julius, H. J.; Li, L.; and Theerachai. C. 2019. Genetic parameters and inbreeding effects for production traits of Thai native chickens. Asian-Australas J Anim Sci. 32:930-938.

Wolc, A.; Kranis, A.; Arango, J.; Settar, P.; Fulton, J. E.; O'Sullivan, N.; Habier, D.; Avendao, S.; Watson, K. A.; Preisinger, R.; Lamont, S. J.; Fernando, R.; Garrick, D. J.; and Dekkers, J. C. M. 2014. Applicationof genomic selection in poultry. In Proceedings $10^{\text {th }}$ World Congress on Genetics Applied toLivestock Production, Vancouver, BC, Canada,August 17-22.

Yavarifard, R.; Ghavi Hossein-Zadeh, N.; and Shadparvar, A. A. 2015. Estimation of genetic parameters for reproductive traits in Mehraban sheep. Czech J. Anim. Sci., 60: 281-288.

Zeller, F. J. 1971. The effect of testosterone and dihydrotestosteronein the comb, testes, and pituitary gland of the male fowl.J. Reprod. Fertil. 25:125-127. 


\section{الملخص العربي \\ الاستجابة الوراثية لبعض مقاييس جسم الأكور والتناسل لاجاج الجميزة المنتخب لمحيط الصدر نبيل جلبي بطرس}

$$
\text { معهد بحوث الإنتاج الحيو انيـ مركز البحوث الزراعية_مصر }
$$

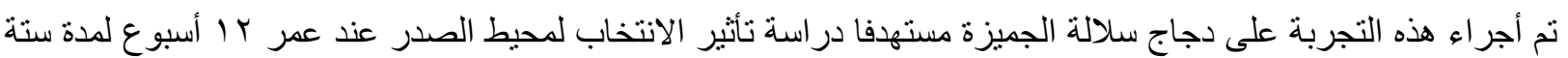

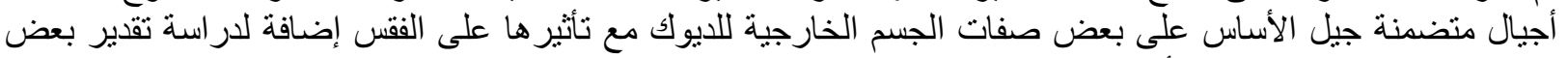

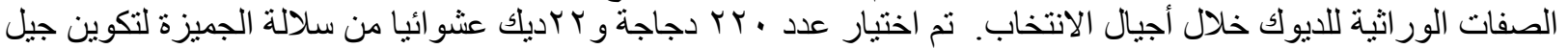

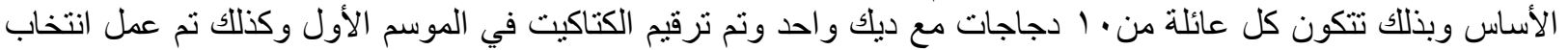

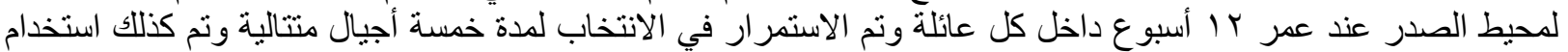

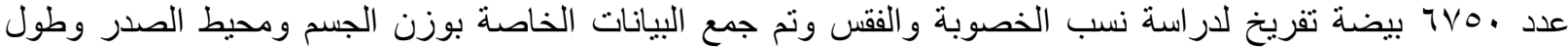

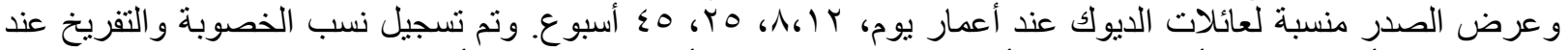

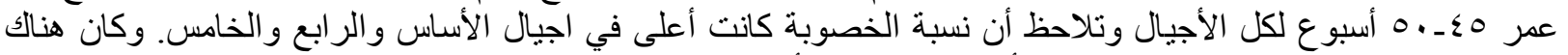

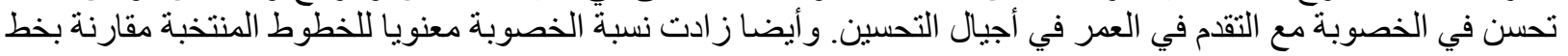
الكنترول وذللك في الجيل الخامس.

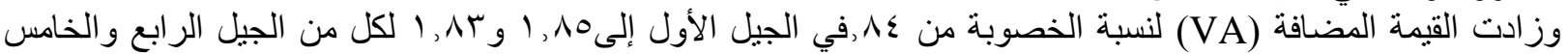

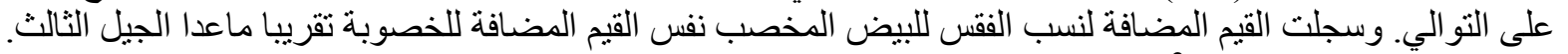

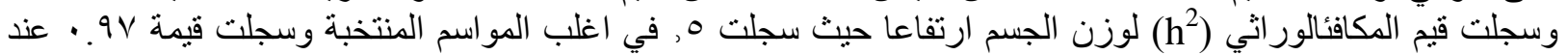

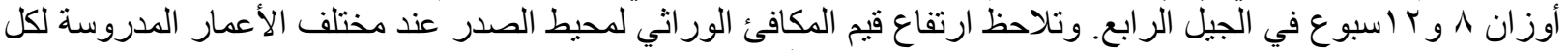

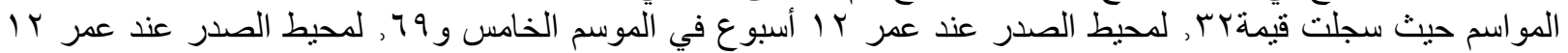

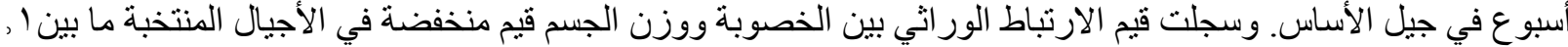

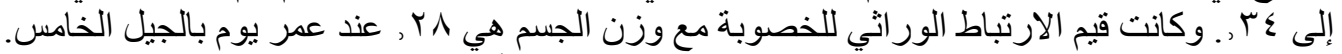

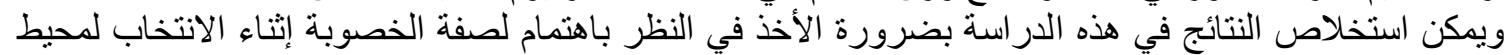
الصدر خشية تدهور هذه الصفة مع استخدام صفات طول ولخدر الترض الصدر في برنامج الدليل الانتخابي. 